\title{
Factors Influencing Corporate Zakat Expenditure (Case Study of Islamic Banks in Indonesia Period 2015-2017)
}

\section{Rizky Utarî, Hilda Monoarfa, and Sri Yayu Ninglasari}

Department of Islamic Economics and Finance, Universitas Pendidikan Indonesia Jl. Dr. Setiabudhi No. 229 Kota Bandung

\section{Abstract}

This study aims to see an overview of the rate of Return on Assets (ROA), Return on Equity (ROE) and Firm Size and its influence on corporate zakat in Islamic Banks in Indonesia period 2015-2017. The method used in this research is causality method with quantitative approach. The population of this study is Islamic Banks registered in Bank Indonesia (BI) with a total sample of five Islamic Banks during three year period. The data was analyzed using panel data regression. The dependent variable used in this study is the corporate zakat expenditure. Furthermore, the independent variables are

Corresponding Author: Rizky Utari

rizkyutari195@student.upi.edu

Received: 10 February 2019

Accepted: 14 March 2019

Published: 28 March 2019

Publishing services provided by Knowledge E

(c) Rizky Utari et al. This article is distributed under the terms of the Creative Commons

Attribution License, which permits unrestricted use and redistribution provided that the original author and source are credited.

Selection and Peer-review under the responsibility of the ICIEBP Conference Committee. Return on Assets (ROA), Return on Equity (ROE) and Firm Size. The results indicated that corporate zakat expenditure on Islamic Banks has increased every year, while ROA and ROE has fluctuating growth. ROA tends to icrease, but ROE tends to decrease. Based on the t-test results show that ROA does not have effect on the corporate zakat expenditure while ROE and Firm Size have a positive and significant effect on corporate zakat expenditure. Thus it can be concluded that when ROA increases, it does not affect the corporate zakat and when ROE and firm size increases, it will increase the corporate zakat on Islamic Banks.

Keywords: Corporate Zakat, ROA, ROE, Firm Size

\section{Introduction}

Islamic bank is a financial institution that develops by carrying out business activities in accordance with the basic principles of Islamic economics. So the purpose of Islamic banks not only profit-oriented but also falah oriented. With the existence of falah oriented, the Islamic bank which is a sharia-based business organization, also oriented to zakat, which can be seen from how much the ability of Islamic banks to issue their zakat (Jaelani, 2016).

Corporate zakat is part of the issue of contemporary zakat which is present in this era. Nurhayati dan Wasilah (2009) stated that corporate zakat according to contemporary 
scholars such as Yusuf Qardhawi and Abu Ubaid can be analogized (qiyas) with zakat commercial.

According to Irfan Syauqi Beik, the potential of corporate zakat in 2016 amounted Rp 116 trillion, while the corporate zakat funds that have been collected based on the data from PUSKAS BAZNAS (2017) amounted to Rp 5 billion per July 2017 from 61 companies. Based on the data from Islamic Banking Statistics (SPS) released by OJK in 2016, stated that the amount of net profit in Islamic Banks (BUS) reached Rp. 2,949 billion, the contribution of zakat by Islamic banks was 73.72 billion (Shohiha, 2017). With the high potential of national zakat, especially in the corporate zakat is not comparable to the zakat funds collected.

Islamic financial institutions, especially Islamic banks in Indonesia are required to pay corporate zakat if they meet the specified requirements. This has been regulated in the Act. No. 38/1999 Clause 11 Paragraph 2 Points b. However, the application of corporate zakat on the field is not as expected. Many things that cause it, include lack of understanding of the community, no fatwa of the National Sharia Board (DSN) MUI about corporate zakat, and the effect of zakat payments on tax payment burden is insignificant (BAZNAS, 2014).

According to data from Islamic Banking Statistics (SPS) 2017 (Otoritas Jasa Keuangan, 2017), the total of Islamic Banks (BUS) in 2017 is 13 banks. However, not all Islamic Banks enclose data on the collection of zakat funds. Based on the reports of Islamic public bank publications on the data and statistics of the financial services of the Financial Services Authority (OJK) there are only eight BUS that report information about the zakat they have issued.

In addition, there are two possibilities that cause the Islamic Banks (BUS) does not report their zakat funds i.e BUS did not practice zakat and on the other hand BUS practiced zakat using institutions or units outside the BUS. For example Bank Syariah Bukopin which does not carry out the function of distributing zakat, infaq, shadaqah funds and qardhul hasan funds directly, but forming a special organization to manage ZIS and qardhul hasan funds. As a result, reporting of ZIS and Qardhul Hasan funds is not presented in the financial statements but reported separately by the zakat management unit they form (Andriani, Rakhmawati, \& Fahmi, 2016).

The corporate zakat issued by 8 Islamic Commercial Banks (BUS) in 2017 which are contained in the BUS Publication Report on the OJK website can be seen in Figure 1. Based on zakat expenditure data from 8 Islamic Banks (BUS) in Figure 1, it can be said that in 2015 to 2017 fluctuated. Of the 8 BUS, Bank Syariah Mandiri is the Islamic bank 
that issues the highest zakat in the last three years. On the contrary BJB Syariah Bank has lowest corporate zakat in 2017 which is Rp. 10,000,000 only.

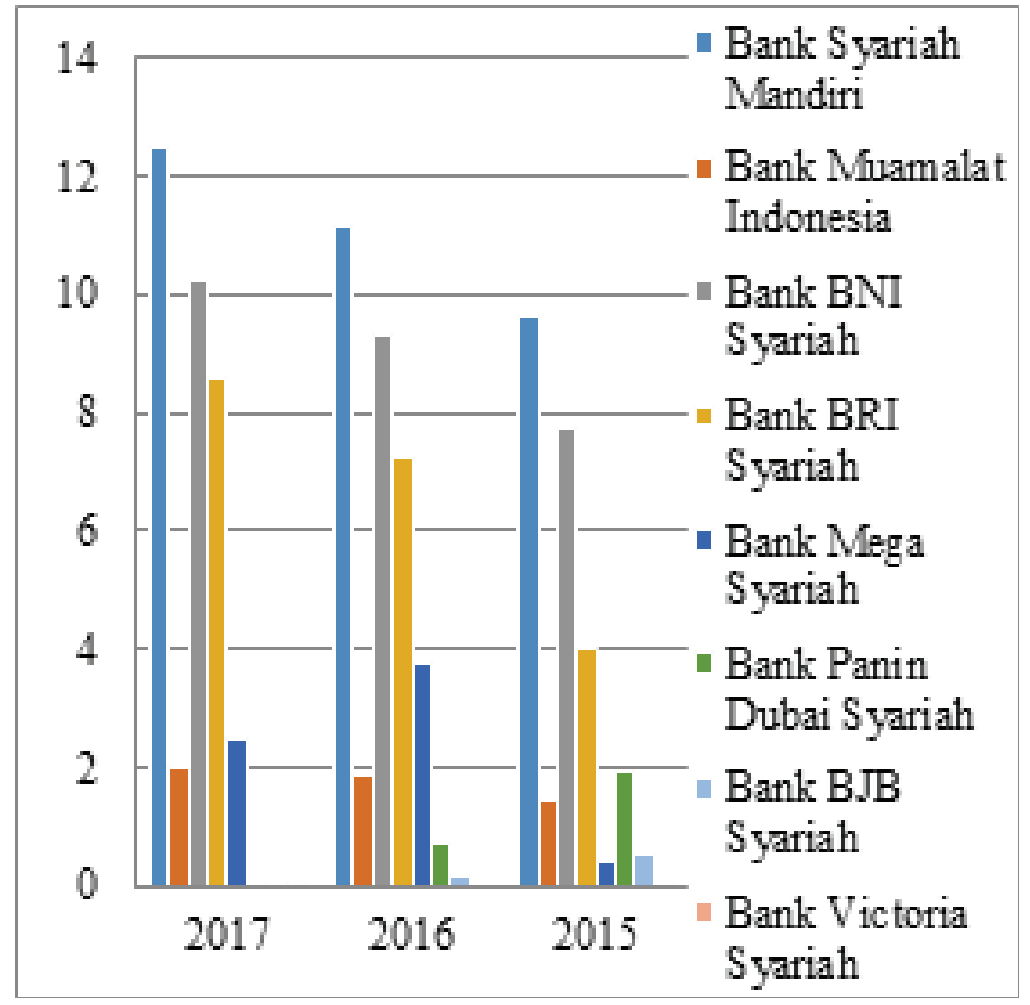

Figure 1: Corporate Zakat on Islamic Banks (In billions of rupiah). (Source: Source and Distribution Report of Islamic Banks Quarterly Zakat Funds by December 2015-2017.)

Financial performance calculated in the profitability ratio is one of the factors that influence the amount of corporate zakat issued by Islamic banks. Profitability in a sharia bank can be measured by the ratio of Return on Assets (ROA) and Return on Equity (ROE). According to the results of research conducted by Herwanti, Irwan, and Fitriyah (2017) shows that Return on Assets (ROA) has a positive and significant effect on the amount of zakat paid by Islamic banks. Besides, research conducted by Masulah, Mardani, and Wahono (2017) shows that Return on Equity (ROE) has a significant and positive effect on the ability of zakat in Islamic banks.

In addition, firm size used in this research as a estimating variable that affects the expenditure of zakat on Islamic banks which can be measured by the total assets of the Islamic Banks (BUS). The size of a company can affect the zakat expenditure by BUS can be strengthened by the results of previous research by Abd Samad, Said, Kamarulzaman, Mahshar, and Mohd Nasir (2015) which explains that firm size has a significant positive effect on the amount of zakat issued.

Corporate zakat issued by the Islamic Banks (BUS) in Indonesia are likely to be influenced by several factors: profitability ratio in this case is Return on Assets (ROA), 
Return on Equity (ROE) and firm size. In this case corporate zakat can prosper the nation. There are also blessings in the assets or the company in this case is Islamic Bank. In addition, corporate zakat issued by BUS can add zakat nationally by BAZNAS (BAZNAS, 2014).

Based on the previous research results and problems of the phenomenon before, then the authors are interested in further researching the factors that influence the expenditure of zakat on Islamic Banks (BUS) in Indonesia.

\section{Literature Review}

Zakat is an obligation which is the command of Allah SWT for every Muslim who has property that has reached nishab and hawl. Zakat is a maaliyah ijtima'iyah worship which has a very important, strategic and decisive position according to the teachings of the Islamic religion and in terms of the welfare development of the people (Hafidhuddin, 2002).

Corporate zakat is a new phenomenon that is based on the principles of justice and the results of ijtihad of the jurists, so it is almost certainly not found in the book of classical jurisprudence (Nurhayati \& Wasilah, 2009). According to BAZNAS Center of Strategic Studies (2017), the corporate zakat is zakat imposed on companies that run their businesses (can act legally, have rights and obligations, and can have their own wealth). In addition, according to Sri Nurhayati and Wasilah (2009), corporate zakat is only required by companies owned (at least the majority) by Muslims. As well as stated by Ismail, Tohirin, \& Ahmad (2013), business entities are obliged to pay zakat on their business subjects for all the requirements set. The legal basis of zakat in the company rests on the arguments in the Qur'an, as in Sura Al-Baqarah verse 267:

Meaning: "O you who have believed, spend from the good things which you have earned and from that which We have produced for you from the earth. And do not aim toward the defective therefrom, spending [from that] while you would not take it [yourself] except with closed eyes. And know that Allah is Free of need and Praiseworthy".

Based on the legal basis above, according to the results of International Conference I on zakat in Kuwait, the company is obliged to issue zakat, because the existence of the company as a place of business becomes a legal entity (reeht person).

Accounting standards relating to zakat assessment refer to accounting guidelines developed to deal with certain financial accounting and reporting issues. AAOIFI has 
issued Financial Accounting Standards No. 9 which specifically regulates the accounting treatment of zakat for Islamic banking and financial institutions (Adnan, 2009).

There are three opinions on how to calculate corporate zakat according to Sri Nurhayati and Wasilah (2009), according to Yusuf Qardhawi corporate zakat can be formulated by:

Corporate Zakat $=($ cash + short-term investment + inventory + net trade receivables $)$ -(short-term liabilities).

Return on Asset (ROA) describes the extent of the return on the total assets owned by the company (Bank Indonesia, 2012). With good financial performance, banks will tend to issue zakat in accordance with religious provisions and statutory provisions. The following is how to calculate the Return on Assets (ROA) ratio according to (Bank Indonesia, 2012):

$$
\mathrm{ROA}=\frac{\text { Income Before Tax }}{\text { Total Asset }} \times 100 \%
$$

Return on Equity (ROE) is a measurement of income available to company owners (both ordinary and preferred shareholders) for the capital they invest in a company (Irawati, 2006). ROE ratio can be calculated by the following formula (Bank Indonesia, 2012):

$$
\mathrm{ROE}=\frac{\text { Income After Tax }}{\text { Equity }} \times 100 \%
$$

Firm size is a scale, which can classify the size of the company in various ways, including: total assets, long size, stock market value etc. (Arif, Alwi, \& Tahir, 2011). Firm size can be calculated by the following formula (Ratnasari, 2016):

$$
\text { Firm Size }=\text { Ln Total Asset }
$$

Zakat is imposed on the wealth and value of assets in Islamic banks with shareholder consensus. Thus, Zakat is mobilized through Islamic banks in the appropriate project syariat in the economy to produce Gross Domestic Product (GDP) related to projects and related sectors (Choudhury \& Harahap, 2008).

\section{Methodology}

The research method used is causality method using a quantitative approach. The samples used were five Islamic Banks namely Bank Syariah Mandiri, BNI Syariah, 
BRISyariah, Bank Muamalat Indonesia, and Bank Mega Syariah from 13 BUS which became the population in this study. This research was conducted in the 2015-2017 period for three years or 36 months. The data used in this study is secondary data. In addition, data collection techniques in this study are documentation studies obtained from the five BUS annual financial reports, as well as monthly BUS publication reports on the OJK website (www.ojk.go.id). Data collection was also carried out through literature study.

The data was analyzed using panel data regression test, it is necessary to select the model that will be used in the research by conducting Chow Test, Hausman Test and the Lagrange Multiplier (LM) Test (Rohmana, 2013). The next step is the classic assumption test. In panel data regression, not all classical assumptions in the OLS method are used, only multicollinearity and heteroscedasticity are needed (Basuki, 2015). In addition, data processing will be presented for panel data regression analysis and hypothesis testing consisting of statistical t test, statistical $f$ test, and determination coefficient $\left(R^{2}\right)$.

\section{Result}

Based on the BUS Publication Report on the OJK website in 2013 , the largest source of zakat funds in Indonesia came from the corporate zakat which amounted to $62 \%$ of the total zakat in BUS. The rest of the BUS zakat funds come from employee and customer, respectively $27 \%$ and $11 \%$. The high source of zakat funds from the BUS entity in Indonesia shows that the corporate zakat contributed the most to BUS's zakat funds in Indonesia in $\mathbf{2 0 1 3}$, of which only three of the nine BUS in Indonesia or 33.3\% paid zakat for their entities (Andriani, Rakhmawati, \& Fahmi, 2016). Corporate zakat on five BUS in Indonesia as a whole has increased every year. However, the Bank Mega Syariah experienced a decline in 2017 of $0.42 \%$. The highest corporate zakat is at Bank Syariah Mandiri (BSM) which is $23.25 \%$ in 2017.

Based on the BUS Publication Report on the OJK website, ROA in five Islamic Banks in Indonesia in 2015-2017 overall experienced fluctuating growth every year, but tends to increase. The five BUS in 2016, it increased, but in 2017 experienced a decline, another case with Bank Syariah Mandiri which stagnated by $0.59 \%$. The highest ROA is at Bank Mega Syariah (BMS) which is $2.63 \%$ in 2016. Besides, ROE in five Islamic Banks in 2015-2017 as a whole experienced fluctuating growth every year, but tended to decline. The highest ROE is at Bank Mega Syariah (BMS) which is $11.97 \%$ in 2016.

In addition, the firm size of the five BUS in Indonesia for the period of 2015 - 2017, BNI Syariah, Bank Syariah Mandiri, BRI Syariah, and Bank Mega Syariah has increased 
every year. On the other hand Bank Muamalat Indonesia has decreased by 0.3 and $0.4 \%$ from 2015 - 2017. Then Bank Syariah Mandiri is the highest in total assets, which is $32.11 \%$ in 2017.

This research conducting Chow Test and Hausman Test as panel data regression selection as follows:

TABLE 1: Chow Test Result.

\begin{tabular}{|c|c|c|c|}
\hline \multicolumn{4}{|c|}{$\begin{array}{l}\text { Redundant Fixed Effects Tests } \\
\text { Equation: Zakat } \\
\text { Test cross-section fixed effects }\end{array}$} \\
\hline Effects Test & Statistic & d.f & Prob. \\
\hline Cross-section F & 79.155350 & $(4,172)$ & 0.0000 \\
\hline Cross-section Chi-square & 187.936826 & 4 & 0.0000 \\
\hline
\end{tabular}

The results shows that the chi-square value is equal to 0.0000 where the value is smaller than the alpha of 0.05 ( $F<0.05)$. It can be concluded that the right model for panel data regression is Fixed Effect Model (FEM).

TABLE 2: Hausman Test Result.

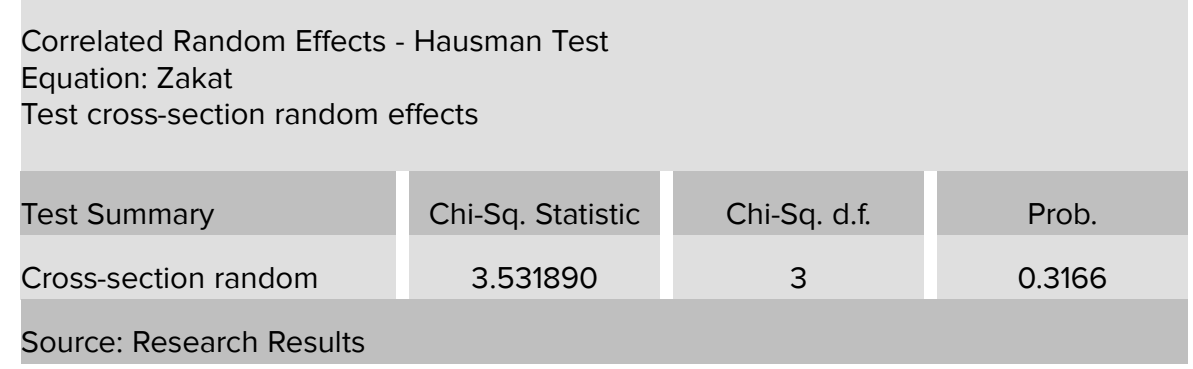

The result shows that the chi-square value is equal to 0.3166 where the value is greater than the alpha value of 0.05 . It can be concluded that the right model for panel data regression is a random effect model. With the selection of random effects, a Langrange Multiplier (LM) test is needed, but there are several considerations that can be used as a guide to choose between the fixed effect model or the random effect model described by Chadidjah and Elfiyan (2009). One of the things that are taken into consideration is that if the $\mathrm{T}$ (number of time series units) is larger while $\mathrm{N}$ (the number of cross section units) is smaller, it is recommended to choose the fixed effect model. Because in this study $\mathrm{T}$ (the number of time series units) is larger while $\mathrm{N}$ (the number of cross section units) is smaller, then Fixed Effect Model (FEM) is chosen. 
From a series of testing panel data models such as Chow and Hausman Test to determine the appropriate regression model and can be used, the two tests show that Fixed Effect Model (FEM) is the best model used with the estimation model as follows:

TABLE 3: Fixed Effect Model (FEM) Result.

\begin{tabular}{l|c|c|c|c}
\multicolumn{5}{c}{ Dependent Variable: Zakat, Method: Pooled Least Squares } \\
\hline Variable & Coefficient & Std. Error & t-Statistic & Prob. \\
\hline C & -0.853410 & 0.851130 & -1.002679 & 0.3174 \\
\hline ROA & 0.008396 & 0.025941 & 0.323667 & 0.7466 \\
\hline ROE & 0.558008 & 0.123459 & 4.519774 & 0.0000 \\
\hline Firm Size & 0.086733 & 0.027543 & 3.149018 & 0.0019 \\
\hline Fixed Effects & & & & \\
\hline (Cross) & & & & \\
\hline _BNIS-C & 0.052983 & & & \\
\hline _BSM-C & -0.005983 & & & \\
\hline _BRIS-C & 0.037355 & & & \\
\hline _BMI-C & -0.126041 & & & \\
\hline _BMS-C & 0.041687 & & & \\
\hline Source: Research Results & &
\end{tabular}

The equation for Fixed Effect Model (FEM) is as follows:

$$
Y_{t i}=X_{t i} \beta+c_{i}+d_{t}+\varepsilon_{t i}
$$

Regression estimation results in Table 3 obtained the following equation:

$$
\begin{aligned}
\text { Zakat BUS }_{i t}= & -0.853410+0,008396 X 1_{i t}+0,558008 X 2_{i t} \\
& +0,086733 X 3_{i t}+0,052983 D 1-0,005983 D 2 \\
& +0,037355 D 3--0,126041 D 4+0,041687 D 5+e_{i t}
\end{aligned}
$$

Based on the model, it can be explained that when ROA (X1), ROE (X2) and Firm Size (X3) are equal to 0 (zero), the corporate zakat issued is $-0.85 \%$. Then when $\mathrm{X} 1$ (ROA) increase $1 \%$, the amount of the corporate zakat expenditure on Islamic Banks (BUS) will increase by $0.008 \%$. When $X 2$ (ROE) increase $1 \%$, then the amount of the corporate zakat expenditure on BUS will increase by $0.56 \%$. As well as the X3 (firm size) increases by $1 \%$, then the amount of the corporate zakat expenditure on BUS will increase by $0.09 \%$

The D1, D2, D3, and D4 are Dummy variables to determine changes in intercepts between companies that explain the effect of differences in each Islamic Banks (BUS). 
Multicollinearity is a condition where there is a linear relationship between independent variables.

TABLE 4: Multicollinearity Test.

\begin{tabular}{l|c|c|c|} 
& ROA & ROE & Firm Size \\
\hline ROA & 1.000000 & -0.029763 & 0.066498 \\
\hline ROE & -0.029763 & 1.000000 & -0.333323 \\
\hline UP & 0.066498 & -0.333323 & 1.000000 \\
\hline \multicolumn{2}{l}{ Source: Research Results } & & \\
\hline
\end{tabular}

Based on the results of the multicollinearity test in Table 4, it can be seen that all the independent variables have a low coefficient that is under 0.80 , so it can be concluded that in this study there is no multicollinearity.

Heteroscedasticity test aims to test whether in a regression model there is residual inequality from one observation to another. Heteroscedasticity test results will be presented in Table 5 as follows.

TABLE 5: Heteroscedasticity Test.

\begin{tabular}{l|c|c|c|c|}
\hline Variable & Coefficient & Std. Error & t-Statistic & Prob. \\
\hline C & 0.001403 & 0.000736 & 1.906658 & 0.0582 \\
\hline ROA & -0.003487 & 0.004441 & -0.785037 & 0.4335 \\
\hline ROE & 0.050901 & 0.038937 & 1.307261 & 0.1929 \\
\hline UP & -0.031338 & 0.023240 & -1.348416 & 0.1793 \\
\hline
\end{tabular}

Based on the heteroscedasticity test results in Table 5, it can be seen that the probability of each independent variable $>0.05$ is the Return on Asset (ROA) variable of $0.4335>0.05$, the Return on Equity (ROE) variable is $0.1929>0,05$, and the Company Size variable is $0.1793>0.05$ so it can be concluded that all independent variables do not occur heteroscedasticity.

Partial test or $t$ test is done with the aim to find out how much influence each independent variable has on the dependent variable. Based on the results of testing using the Eviews application program it will be explained in the discussion of the $t$ test of each of the following independent variables:

The result of t-Test value on ROA is 0.32 smaller than t table (1.973534) which means accepting $\mathrm{H}_{0}$ and rejecting $\mathrm{H}_{1}$. Furthermore, the probability level of 0.7466 is greater than $\alpha=(0.05)$ so it can be concluded that ROA has no effect and not significant on corporate zakat expenditure on BUS. Thus, the results of this study reject the hypothesis 
TABLE 6: t-Test Result of ROA, ROE, Firm Size on Corporate Zakat.

\begin{tabular}{l|c|c|c|c|}
\hline Variable & Coefficient & Std. Error & t-Statistic & Prob. \\
\hline ROA & 0.0084 & 0.0259 & 0.3237 & 0.7466 \\
\hline ROE & 0.5580 & 0.1235 & 4.5198 & 0.0000 \\
\hline Firm Size & 0.0867 & 0.0275 & 3.1490 & 0.0019 \\
\hline
\end{tabular}

which states that there is a positive influence between ROA and the expenditure of corporate zakat on Islamic Banks during the period of January 2015 - December 2017.

Unlike research conducted by Herwanti, Irwan, and Fitriyah (2017) which uses ROA as one of the independent variables explains that ROA has a positive and significant effect on the amount of zakat paid by Islamic banks. Similarly, the results of research conducted by Muhammad (2016) that uses ROA as one of the independent variables with the result that profitability has a positive and significant effect on the compliance of corporate zakat to Muslim entrepreneurs in small and medium sectors in Malaysia.

Thus, based on the findings in this study that are associated with theoretical concepts and supported by empirical facts of previous research it can be concluded that ROA does not has positive effect and significant to the corporate zakat expenditure of Islamic Banks (BUS) in Indonesia, so the results of this research is not suitable and does not support the previous studies results.

Then, the result of $t-T e s t$ value on ROE is 4.52 greater than $t$ table (1.973534) which means rejecting $\mathrm{H}_{0}$ and accepting $\mathrm{H}_{1}$. The probability level is 0.0000 which is smaller than $\alpha=(0.05)$, so it can be concluded that ROE has a significant effect and positive direction to the corporate zakat expenditure on Islamic I Banks (BUS). This shows that every increase in ROE of $1 \%$ will affect the increase in corporate zakat issued by the BUS of $0.56 \%$. Thus the results of testing the second hypothesis regarding the effect of ROE on corporate zakat expenditure on Islamic Commercial Banks (BUS) during the period January 2015 to December 2017 shows that ROE has a positive and significant effect of corporate zakat on BUS. Islamic banks that have good financial performance will be related to the expenditure of zakat if it is viewed through the business concept. When the Islamic bank has a good financial performance, the bank will tend to issue zakat in accordance with Islamic provisions and legislation (Firmansyah \& Rusydiana, 2013).

Previous research conducted by Masulah, Mardani, and Wahono (2017), and Herwanti, Irwan, and Fitriyah (2017) who use ROE as an independent variable explains that Return on Equity (ROE) has a significant and positive effect on zakat ability of Islamic Banks 
(BUS) in Indonesia. While the research conducted by Abd Samad, Said, Kamarulzaman, Mahshar, and Normaya (2015) states that ROE has a negative and insignificant effect on the amount of corporate zakat issued by Islamic banks in Malaysia.

Thus, based on the findings of this study that are associated with theoretical concepts and supported by empirical facts of previous research it can be concluded that ROE has a significant and positive effect of corporate zakat issued by BUS in Indonesia, so that the results of this study are appropriate and support several results of previous studies.

Furthermore, the result of t-Test value on firm size is 3.15 greater than t table (1.973534) which means rejecting $\mathrm{H}_{0}$ and accepting $\mathrm{H}_{1}$. The probability level of 0.0019 is smaller than $\alpha=(0.05)$ so it can be concluded that the firm size has a significant and positive effect of the corporate zakat expenditure on Islamic Banks (BUS). This shows that every increase in Company Size by $1 \%$, it will affect the increase in corporate zakat issued by BUS by $0.09 \%$. Thus, the effect of the Firm Size on the expenditure of zakat on Islamic Banks (BUS) during the period January 2015 to December 2017 as the third hypothesis showed that the Firm Size had a positive and significant effect of corporate zakat on BUS. There have been several previous studies that examined the effect of Company Size on corporate zakat issued by Islamic banks, such as research conducted by Abd Samad, Said, Kamarulzaman, Mahshar, and Mohd Nasir (2015) who used firm size as one independent variable explaining that firm size has a positive and significant effect on the amount of zakat issued to Islamic banks in Malaysia.

Thus, based on the findings in this study that are associated with theoretical concepts and supported by empirical facts of previous research it can be concluded that the size of the company has a significant effect on the positive direction of corporate zakat issued by Islamic Commercial Banks (BUS) in Indonesia, so the results of the research this is appropriate and supports some of the results of previous studies.

Beside t-test, simultaneous tests ( $F$ - Test) need to be done to determine whether the independent variables included in the model have an influence on the dependent variable. Based on the results of testing hypotheses, it can be seen the influence or attachment between independent variables on the dependent variable simultaneously or together.

TABLE 7: F-Test.

\begin{tabular}{l|r}
\hline F-statistic & 87.88856 \\
\hline Prob (F-statistic) & 0.000000 \\
\hline Source: Research Results
\end{tabular}


Based on the result on Table 7, it is known that F-statistic (87.89) is greater than $\mathrm{F}$ table (2.66), and the probability (0.000000) is smaller than the level of significance (0.05). Thus, it can be concluded that all independent variables, namely ROA, ROE and Company Size jointly influence the dependent variable, namely the issuance of corporate zakat of Islamic Commercial Banks (BUS).

The next result is the determination coefficient $\left(R^{2}\right)$ which explains how much the percentage of the total variation of the dependent variable is explained in the research model.

TABLE 8: R-Squared Result.

\begin{tabular}{l|c|}
\hline & $\begin{array}{c}\text { Nilai Adjust } \\
\text { R-Squared }\end{array}$ \\
\hline Adjust R-Squared & 0.772618 \\
\hline Source: Research Results
\end{tabular}

This research using panel data regression analysis with a fixed effect model shows that the adjusted $\mathrm{R}$-Square is 0.772618 . This shows that 77.2618 percent of the corporate zakat expenditure on Islamic Banks (BUS) can be explained by the independent variables, namely ROA, ROE, and Firm Size. While the rest (100 percent -77.2618 percent $=$ 22.7382 percent) is explained by other factors outside the research model.

\section{Conclusion}

Corporate zakat issued by Islamic Banks (BUS) for the period of 2015 - 2017 of the five BUS that were sampled in this research as a whole always experienced an increase every year, but Bank Mega Syariah experienced decreased in 2017. The decrease of the corporate zakat growth due to a decrease in the rate of return of all assets owned by the company and also a decrease in available income for the owners of the company. The ROA of the five Islamic Banks experienced a fluctuating growth every year, but tended to increase, another case with ROE from five Islamic Banks which experienced fluctuating growth every year, but tended to decline. While the firm size as measured by the total assets of the five BUS has increased every year, but at Bank Muamalat Indonesia has decreased every year from 2015 - 2017.

Return on Asset (ROA) does not have a positive and significant effect on the expenditure of corporate zakat on Islamic Banks in Indonesia. The level of ROA that experiences fluctuating growth but tends to increase has not been able to influence zakat issued by BUS. On the other hand, ROE has a positive and significant effect on the expenditure of 
zakat on BUS in Indonesia. If the profits incurred by the company on the income available to the owners of the company for the capital they invest experience an increase in the corporate zakat issued by the BUS will also increase.

In addition, the Firm Size has a positive and significant effect to the corporate zakat expenditure of Islamic Banks in Indonesia. The firm size which is measured by the total assets of the company, in this case is the BUS describes the size of the company. If the firm size increase, the corporate zakat issued will be increase.

\section{References}

[1] Abd Samad, K., Said, R., Kamarulzaman, M. H., Mahshar, M., \& Normaya, I. (2015). Exploring the Zakat Payment and Firm's Performance of Islamic Banks in Malaysia. The 6th International Conference on Governance, Fraud, Ethics and Social Responsibility (hal. 6). Merbok, Kedah, Malaysia: Research Management Center at the Universiti Teknologi MARA.

[2] Adnan, M. (2009). Accounting treatment for corporate zakat: a critical review. International Journal of Islamic and Middle Eastern Finance and Management. Vol. 2 No.1, 34.

[3] Andriani, Rakhmawati, A., \& Fahmi, M. Y. (2016). Analisis Potensi Zakat Entitas Pada Bank Umum Syariah di Indonesia. Prosiding Seminar Nasional Politeknik Negeri Banjarmasin (hal. 46). Banjarmasin: Politeknik Negeri Banjarmasin.

[4] Arif, H. M., Alwi, K., \& Tahir, A. M. (2011). Factors Influence Company Towads Zakat Payment: An Explanatory Studies. Second International Conference on Business and Economic Research (2nd ICBER 2011) Proceeding (hal. 2520). Bandar Baru Nilai Negeri Sembilan: Faculty of Economics \& Muamalat Universiti Sains Islam Malaysia.

[5] Bank Indonesia. (2012). Kodifikasi Peraturan Bank Indonesia Kelembagaan Penilaian Tingkat Kesehatan Bank . Pusat Riset dan Edukasi Bank Sentral, 184.

[6] Basuki, A. (2015). Regresi Dalam Penelitian Ekonomi dan Bisnis. Yogyakarta: Danisa Media .

[7] BAZNAS . (2014, April-Mei). Zakat Menyucikan Harta Dan Jiwa. Zakat Perusahaan Dan Potensinya. Jakarta, DKI Jakarta, Indonesia.

[8] BAZNAS, P. (2017). Kewajiban Zakat Perusahaan. Berita Resmi Pusat Kajian Strategis Badan Amil Zakat Nasional, 9.

[9] Chadidjah, A., \& Elfiyan, I. (2009). Model Regresi Data Panel untuk Menaksir Realisasi Total Investasi Asing dan Dalam Negeri. Prosiding Seminar Nasional Matematika dan Pendidikan Matematika Jurusan Pendidikan Matematika FMIPA UNY, 694. 
[10] Choudhury, M., \& Harahap, S. (2008). Interrelationship between Zakat, Islamic bank and the economy A theoretical exploration. Managerial Finance. Vol. 34 No. 9.

[11] Firmansyah, I., \& Rusydiana, A. (2013). Pengaruh Profitabilitas terhadap Pengeluaran Zakat pada Bank Umum Syariah di Indonesia dengan Ukuran Perusahaan Sebagai Variabel Moderasi. Jurnal Liquidity, 115.

[12] Hafidhuddin, D. (2002). Zakat Dalam Perekonomian Modern. Jakarta: Gema Insani.

[13] Herinza, R. (2013). Persepsi Ulama Terhadap Pelaksanaan Perbankan Syariah di Kabupaten Kudus. Universitas Negeri Semarang: Skripsi.

[14] Herwanti, T., Irwan, M., \& Fitriyah, N. (2017). Disclosure Level's Effect of Islamic Social Reporting on Company's Profitability and Zakat. Management and Administrative Sciences Review e-ISSN: 2308-1368, p-ISSN: 2310-872X. Vol. 6, Issue 2, 85.

[15] Huston, S. J. (2010). Measuring financial literacy. Journal of Consumer Affairs, XLIV(2), 296-316.

[16] Irawati, S. (2006). Manajemen Keuangan. Bandung: Pustaka.

[17] Ismail, A., Tohirin, A., \& Ahmad, M. (2013). Debate on Policy Issues in the Field of Zakat on Islamic Bank Business . IRTI Policy Paper 1435-03.

[18] Ismal, R. (2011). Islamic Banking in Indonesia: Lesson Learned. Kertas Kerja dalam Multiyear Expert Meeting on Services, Development and Trade: The Regulatory and Institutional Dimension. United Nations Conference on Trade and Development (UNCTAD), (hal. 1-14). Geneva.

[19] Isnurhadi. (2014). Pentingnya Pemahaman Tentang Keuangan dan Perbankan Syariah dalam Rangka Mu'amalah yang Berdasarkan Syariah Islam. Orasi Ilmiah, $1-25$.

[20] Jaelani, A. (2016). Zakat Accounting: Metaphor and Accounting Treatment For Business Organization. MPRA Paper , 18.

[21] Machmud, A., \& Rukmana. (2010). Bank Syariah. Jakarta: Erlangga.

[22] Masulah, S., Malavia Mardani, R., \& Wahono, B. (2017). Analisis Pengaruh Kinerja Keuangan Terhadap Kemampuan Zakat pada Bank Syariah (Studi Kasus pada Bank Syariah Tahun 2012-2015). e - Jurnal Riset Manajemen Prodi Manajemen, 8.

[23] Md Arif, H., Alwi, K., \& Tahir Munalis, A. (2011). Factors Influence Company Towads Zakat Payment: An Explanatory Studies. Second International Conference on Business and Economic Research (2nd ICBER 2011) Proceeding (hal. 2520). Bandar Baru Nilai Negeri Sembilan: Faculty of Economics \& Muamalat Universiti Sains Islam Malaysia.

[24] Muhammad, I. (2016). Factors That Influence Business Zakat Compliance Among Small And Medium. JMFIR Vol.13 No.1, 107. 
[25] Noor, F. (2012). Preferensi Masyarakat Pesantren Terhadap Bank Syariah (Studi Kasus DKI Jakarta). TAZKIA Islamic Business and Finance Review, 65-79.

[26] Nurhayati, S., \& Wasilah. (2009). Akuntansi Syariah di Indonesia. Jakarta: Salemba Empat.

[27] Otoritas Jasa Keuangan. (2017). Statistik Perbankan Syariah . Jakarta: OJK.

[28] Ratnasari, L. (2016). Pengaruh Leverage, Likuiditas, Ukuran Perusahaan Terhadap Profitabilitas Pada Perusahaan Otomotif di BEl. Jurnal IImu dan Riset Manajemen. Vol. 5, No. 6, 5.

[29] Rohmana, Y. (2013). EKONOMETRIKA Teori dan Aplikasi dengan Eviews. Bandung: Laboratorium Pendidikan Ekonomi dan Koperasi UPI.

[30] Rusdianto, H., \& Ibrahim, C. (2016). Pengaruh Produk Bank Syariah Terhadap Minat Menabung Dengan Persepsi Masyarakat Sebagai Variabel Moderating Di Pati. Equilibrium, IV(1), 43-61.

[31] Sari, M. D., Bahari, Z., \& Hamat, Z. (2013). Perkembangan Perbanakn Syariah di Indonesia: Suatu Tinjauan. Jurnal Aplikasi Bisnis, III(2), 120-138.

[32] Shohiha, A. (2017, Februari 24). Spesialnya Laporan Dana Zakat Bank Syariah. Dipetik Febrruari 15, 2018, dari Kompasiana: https://www.kompasiana.com/aaqied/ spesialnya-laporan-dana-zakat-bank-syariah_58af3aa6c6afbd961c3ba32f

[33] Wartoyo. (2014). Persepsi Dan Respon Pesantren Terhadap Implementasi Ekonomi Islam. Diambil kembali dari Portal Garuda: http://download.portalgaruda.org/ article.php?article=447042\&val=9458\&title=PERSEPSI\%20DAN\%20RESPON\% 20pesantren\%20\%20terhadap\%20implementasi\%20ekonomi\%20islam. 